AT-TAJDID: Jurnal Pendidikan Dan Pemikiran Islam

(p-ISSN: 2548-5784 le-ISSN: 2549-2101)

Vol. (04)(01), (Januari-Juni) (2020), (Halaman)(56-66)

Doi: http://dx.doi.org/10.24127/att.v4i01.1224

\title{
EFEKTIFITAS METODE STAD (STUDENT TEAMS-ACHIEVEMENTS DIVISION) PADA MATERI LARANGAN PERGAULAN BEBAS DAN MENDEKATI ZINA DAPAT MENINGKATKAN PRESTASI BELAJAR SISWA KELAS X IPA 1 SEMESTER GANJIL SMA NEGERI 3 METRO TAHUN PELAJARAN 2016/2017
}

\author{
Elyana \\ SMA Negeri 3 Metro \\ Elyanaana433@gmail.com
}

\begin{abstract}
Abstrak
Tujuan dari penelitian ini adalah untuk melihat efektifitas penggunaan metode STAD (Student Teams Achievement Division) dalam materi larangan pergaulan bebas dan mendekati zina dapat meningkatkan prestasi belajar siswa. Metode penelitian yang digunakan adalah tindakan kelas (Classroom Action Research). penelitian tindakan kelas ini menggunakan model desain siklus milik Kemmis dan Mc Taggart. Teknik pengumpulan data dengan cara observasi, wawancara dengan kawan sejawat, dan untuk analisis data peneliti menggunakan analisis diskriptif kualititatif dengan melakukan triangulasi setelah semua data terkumpul.

Berdasarkan hasil penelitian, didapatkan bahwa Metode STAD memiliki dampak positif dalam meningkatkan prestasi belajar siswa. Hal ini dapat dilihat dari semakin meningkatnya pemahaman siswa terhadap materi yang disampaikan guru pada setiap siklus. Dari hasil tes siklus I hanya $23(65,78 \%)$ siswa yang mencapai ketuntasan secara individu dan yang belum tuntas terdapat 12 siswa (34,32\%) yang belum mencapai ketuntasan. Ketidaktuntasan disebabkan karena pada siklus I masih banyak siswa yang belum paham terhadap materi ajar dan kurang serius dalam mengerjakan soal, hal tersebut merupakan salah satu faktor yang dapat mempengaruhi prestasi belajar siswa. Adapun faktor yang dapat mempengaruhi prestasi belajar siswa adalah faktor internal, dimana faktor internal itu meliputi aspek fisiologi dan aspek psikologi. Aspek fisiologi ini adalah kesehatan tubuh siswa itu sendiri sedangkan aspek psikologi adalah kemapuan, minat dan prestasi belajar siswa itu sendiri. Pada siklus II dan III prestasi belajar siswa sudah mengalami peningkatan, adapun nilai presentase yang diperoleh pada siklus II adalah $85,80 \%$ (30) siswa yang mencapai ketuntasan secara individu dan $14,30 \%$ (5) siswa yang belum mencapai ketuntasan belajar, dan pada siklus III semua siswa tuntas dalam mengerjakan tugasnya tidak ada yang tidak tuntas. Pada siklus II dan III siswa sudah mulai serius dan sudah paham terhadap materi yang telah diajarkan. Hal ini sangatlah bermakna pada kedua siklus ini, proses pembelajarannya sudah mencapai ketuntasan dengan kategori baik sekali. Baik secara individu maupun kelompok.
\end{abstract}

Kata Kunci: STAD (Student Teams Achievement Division), prestasi belajar 


\begin{abstract}
The purpose of this study is to look at the effectiveness of using the STAD (Student Teams Achievement Division) method in prohibiting promiscuity and approaching adultery can improve student achievement. The research method used is class action (Classroom Action Research). This class action research uses the Kemmis and Mc Taggart cycle design models. Data collection techniques by observation, interviews with colleagues, and for data analysis researchers used a qualitative descriptive analysis by triangulating after all data were collected

Based on the results of the study, it was found that the STAD Method has a positive impact on improving student learning achievement. This can be seen from the increase in students' understanding of the material delivered by the teacher in each cycle. From the results of the first cycle test, only $23(65.78 \%)$ students achieved completeness individually and 12 students (34.32\%) had not yet completed. The incompleteness caused by the first cycle there are still many students who do not understand the teaching material and are not serious in working on the problem, it is one of the factors that can affect student achievement. Factors that can affect student achievement are internal factors, where internal factors include physiology and psychological aspects. This physiological aspect is the health of the student's own body while the psychological aspect is the ability, interest, and learning achievement of the students themselves. In cycle II and III students' learning achievement has increased, while the percentage value obtained in cycle II is $85.80 \%$ (30) students who have achieved mastery individually and $14.30 \%$ (5) students who have not reached mastery learning, and in cycle III, all students are complete in doing their work, none are incomplete. In cycle II and III students have started to be serious and have understood the material that has been taught. This is very meaningful in both cycles, the learning process has reached its completeness with a very good category. Both individually and in groups
\end{abstract}

Keywords: STAD (Student Teams Achievement Division), Learning Achievement

\section{A. PENDAHULUAN}

Pesatnya perkembangan dunia pendidikan yang membuat peranan siswa semakin dituntut. Siswa menjadi pusat perhatian dalam proses belajar, sedangkan guru hanya sebagai fasilitator dan pembimbing dalam proses belajar mengajar (Sudjana, 2005). Peranan siswa dituntut menjadi aktif dan mandiri dalam proses pembelajaran berlangsung di kelas dengan alasan untuk melatih diri agar terbiasa dengan cara belajar yang mandiri tanpa harus tergantung pada guru dan bisa memperoleh keberhasilan prestasi belajar yang bagus. Guru hanya bertugas sebagai mediator dan evaluator untuk mencapai tujuan dalam kegiatan proses belajar (Slavin, 2005). Namun keberhasilan pembelajaran juga ditentukan oleh faktor metode guru memberikan materi belajar. Metode pembelajaran yang diberikan kepada siswa merupakan faktor utama daya tarik dan minat belajar siswa untuk menjadi aktif dalam proses belajar mengajar .

Menurut Sugiyono (2009), daya tarik suatu mata pelajaran ditentukan oleh dua hal yaitu oleh mata pelajaran itu sendiri dan cara mengajar guru. Kebanyakan guru dalam cara mengajar cenderung menghafal yang mengakibatkan siswa menjadi pasif dalam belajar. Situasi cara mengajar yang demikian membuat kurangnya keaktifan siswa dalam belajar di kelas dan siswa merasa bosan. Oleh 
karena itu, tugas seorang guru yang profesional menjadikan proses belajar yang sebelumnya tidak menarik menjadi menarik, yang sulit menjadi mudah dan yang tadinya tidak berarti menjadi bermakna dengan metode-metode pembelajaran yang bervariasi.

Seorang guru perlu mengetahui dan dapat menerapkan beberapa prinsip mengajar agar ia dapat melaksanakan tugasnya secara profesional, yaitu:

a. Guru harus dapat membangkitkan perhatian siswa pada mata pelajaran yang diberikan dan dapat menggunakan berbagai media serta sumber belajar yang bervariasi.

b. Guru harus dapat membangkitkan minat siswa untuk aktif dalam berpikir, mencari dan menemukan sendiri pengetahuan.

c. Guru perlu menghubungkan pelajaran yang akan diberikan dengan pengetahuan yang telah dimiliki siswa.

d. Sesuai dengan prinsip repetisi dalam proses pembelajaran, diharapkan guru dapat menjelaskan unit pelajaran secara berulang-ulang sehingga tanggapan siswa semakin jelas.

e. Guru wajib memperhatikan dan memikirkan korelasi antara mata pelajaran dan praktik nyata dalam kehidupan sehari-hari.

f. Guru harus tetap menjaga konsentrasi belajar para siswa dengan cara memberikan kesempatan berupa pengalaman secara langsung, mengamati, dan menyimpulkan pengetahuan yang didapatnya (Hamzah, 2007).

Seperti halnya yang terjadi pada siswa kelas X IPA1SMA Negeri 3 Metro dalam mengikuti proses pembelajaran masih belum bisa berkonsentrasi, siswa masih ribut sendiri dan minat siswa terhadap mata pelajaran khususnya mata pelajaran PAI (Pendidikan Agama Islam) masih rendah. Pembelajaran yang dilaksanakan di SMA Negeri 3 Metro kelas $\mathrm{X}$ IPA1pada pembelajaran PAI khususnya pada materi larangan pergaulan bebas dan mendekati zina masih bersifat tradisional yakni melalui metode ceramah, tanya jawab, dan pemberian tugas. Disamping itu, dalam proses belajar mengajar guru hanya berpedoman pada buku paket saja.

Metode ceramah menyebabkan siswa cenderung lebih cepat bosan dan proses pembelajaran di kelas masih berpusat pada guru, sehingga menyebabkan keaktifan dan prestasi belajar siswa dalam pembelajaran relatif rendah. Siswa hanya mendengarkan penjelasan dari guru yang menyebabkan konsentrasi siswa dalam menerima materi menjadi rendah karena proses pembelajaran kurang memberikan kesempatan bagi siswa untuk aktif dalam pembelajaran. Selain itu, lamanya jam pembelajaran yaitu 2 x 45 menit juga membuat siswa cenderung merasa jenuh. Pada saat pembelajaran di kelas, ditemukan bahwa terdapat siswa yang mengantuk, mengobrol dengan teman lain, dan juga siswa tidak bisa menjawab dengan optimal saat guru memberikan pertanyaan.

Permasalahan tersebut terjadi karena metode pembelajaran kurang memberikan kesempatan bagi siswa untuk lebih aktif, sehingga menyebabkan prestasi belajar siswa kurang optimal. Untuk mengatasi masalah tersebut, maka diperlukan metode pembelajaran yang dapat menyebabkan siswa lebih aktif pada saat proses pembelajaran di kelas berlangsung yaitu dengan metode 
pembelajaran STAD (Student TeamsAchievements Division) yang merupakan metode pembelajaran yang menuntut siswa untuk aktif belajar (Slavin, 2005). STAD (Student Teams Achievement Division) adalah metode yang paling sederhana dalam pembelajaran kooperatif, sehingga akan memudahkan bagi guru untuk mengajar pada setiap mata pelajaran khususnya mata pelajaran PAI materi larangan pergaulan bebas dan mendekati zina. Dalam pembelajaran kooperatif metode STAD digunakan sistem skor yang lebih menekankan pencapaian kemajuan daripada sekedar persentase jawaban yang benar. Ide dasar STAD adalah bagaimana memotivasi dan menguasai materi yang disajikan serta menumbuhkan kesadaran bahwa belajar itu penting, bermakna dan menyenangkan.

Berdasarkan permasalahan yang dikemukakan diatas, maka peneliti ingin menyoroti dan melihat lebih dalam bagaimanakah efektifitas dari metode STAD
(Student Teams Achievement Division) dalam materi larangan pergaulan bebas dan mendekati zina dapat meningkatkan prestasi belajar siswa

\section{A. METODOLOGI}

Dalam penelitian ini, peneliti menggunakan tindakan kelas (Classroom Action Research) (Arikunto, 2007) yang didesain untuk memecahkan masalah yang peneliti paparkan pada bagian latar belakang. Penelitian tindakan kelas ini menggunakan model desain siklus milik Kemmis dan Mc Taggart (Kusumah \& Dwitagama, 2010). Metode pengumpulan data dengan cara observasi, wawancara dengan kawan sejawat dan untuk analisis data peneliti menggunakan analisis diskriptif kualititatif dengan melakukan triangulasi setelah semua data terkumpul (Moleong, 2013). Di bawah ini gambaran siklus yang dikembangkan oleh Kemmis dan Mc Taggart yang akan peneliti gunakan, sebagai berikut :

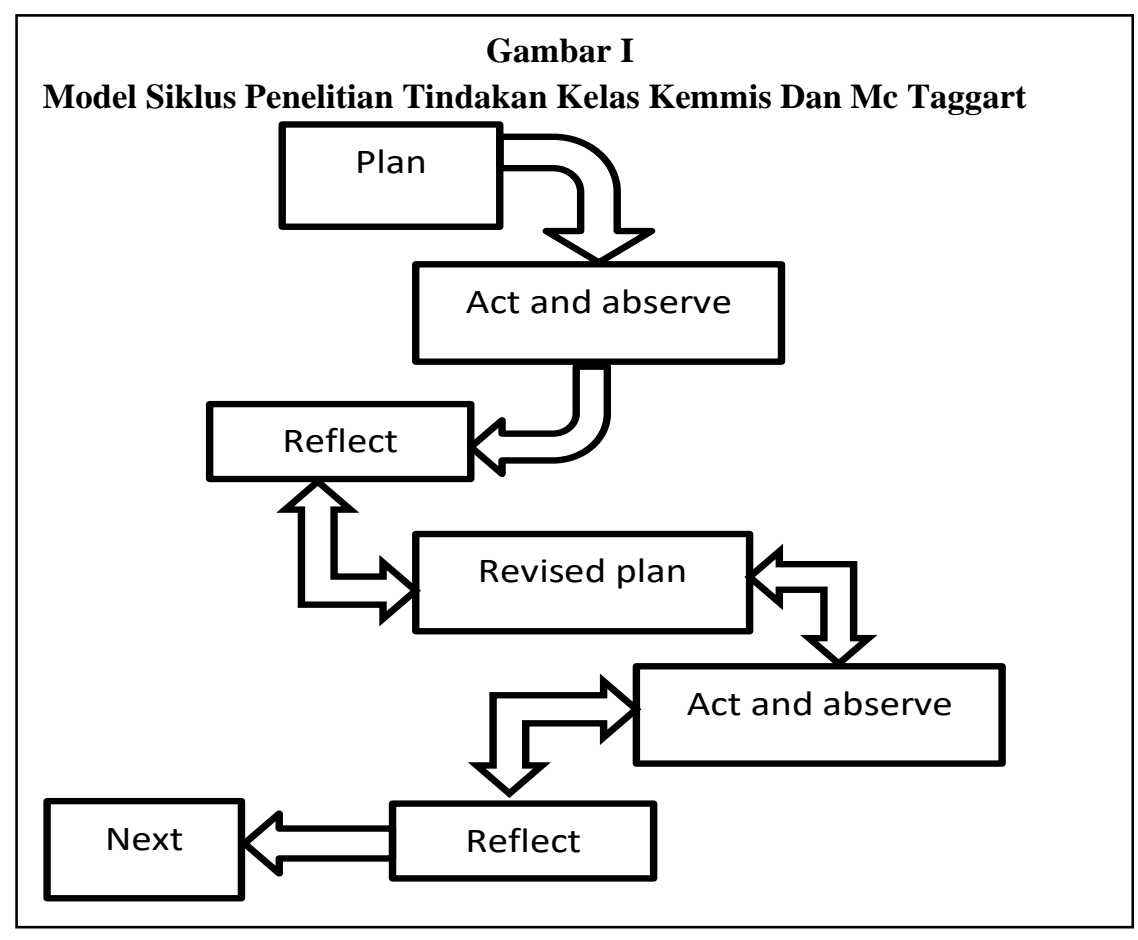

Copyright () 2020, Universitas Muhammadiyah Metro| 59 


\section{B. HASIL DAN PEMBAHASAN}

\section{Penerapan Metode STAD (Student Teams Achievement Division) di SMA Negeri 3 Metro}

Pembelajaran merupakan proses yang kompleks, di dalamnya mencakup proses/kegiatan belajar dan kegiatan mengajar (Baharudin, 2008). Kegiatan pembelajaran mengacu pada pengunaan metode dalam rangka membangun proses belajar. Oleh sebab itu, penggunaan metode dalam pembelajaran harus dipilih dengan benar agar dapat mengoptimalkan tujuan pembelajaran. Sebagaimana hasil wawancara yang dikemukakan oleh Kepala Sekolah SMA Negeri 3 Metro bahwa untuk mencapai tujuan pembelajaran sesuai dengan tujuannya harus menerapkan metode pembelajaran yang bervariasi dan inovasi agar siswa tertarik untuk belajar dan tujuan pembelajaran tercapai secara optimal.

Awal proses penelitian, peneliti melakukan diskusi dan observasi dengan para guru PAI (Pendidikan Agama Islam) lainnya yang bertujuan untuk memberikan informasi kepada para guru PAI lainnya mengenai penelitian yang akan dilakukan oleh peneliti dan untuk mengetahui beberapa permasalahan yang dihadapi oleh para guru saat melaksanakan proses pembelajaran PAI di kelas. Sebagaimana yang dikemukakan oleh salah satu guru PAI lainnya bahwa pada saat proses pembelajaran siswa banyak yang tidak mendengarkan guru didepan menjelaskan materi yang sedang diajarkan banyak yang mengobrol oleh karena hal tersebut menjadi permasalahan guru yang kerap banyak dirasakan oleh semua guru sehingga guru harus mencari metode pembelajaran yang cocok supaya murid mau belajar dan tidak ribut sendiri ketika sedang dalam proses pembelajaran.

Guru PAI di kelas X IPA1SMA Negeri 3 Metro semester ganjil tahun pelajaran 2016/2017 sudah banyak yang menggunakan berbagai metode pembelajaran supaya tujuan pembelajaran tercapai dan siswa aktif dalam belajar. Salah satu metode yang dikaji dalam penelitian ini adalah penerapan metode STAD (Student Teams Achievement Division). Langkah pembelajaran STAD yang dilaksanakan dalam penelitian ini adalah sebagai berikut:

1. Guru menyampaikan materi pembelajaran, melalui presentasi kelas.

2. Guru membagi siswa ke dalam beberapa kelompok, setiap kelompok terdiri 4-5 murid yang heterogen.

3. Diskusi kelompok untuk penguatan materi.

4. Guru memberikan tes secara individual

5. Guru memberi poin lebih (reward) kepada kelompok yang memiliki nilai rata-rata tertinggi

Metode STAD diterapkan dalam kelas X IPA1SMA Negeri 3 Metro semester ganjil tahun pelajaran 2016/2017 pada materi larangan pergaulan bebas dan mendekati zina, adapun deskripsi dari hasil penelitian pada setiap siklus, yaitu:

\section{Siklus I}

Pada siklus I dilaksanakan pada hari Kamis tanggal 7 Agustus 2014 pada jam pelajaran 1-3 dengan waktu perjamnya 45 menit sehingga total waktu untuk proses pembelajaran materi larangan pergaulan bebas dan mendekati zina khususnya pada kompetensi dasar menganalisis Q.S Al-Isra': 
32 dan Q.S An-Nur: 2 serta hadits tentang larangan pergaulan bebas dan perbuatan zina berlangsung selama 135 menit dengan jumlah siswa 35 orang.

Pada siklus I, guru memulai pembelajaran dengan apersepsi menyampaikan tujuan pembelajaran. Pertanyaan dilontarkan kepada siswa mengenai Q.S surat apa dan ayat berapa yang menjelaskan tentang pergaulan bebas dan zina. Guru menjelaskan penggunaan metode pembelajaran STAD kepada siswa, dan langkah-langkah yang harus dilakukan oleh siswa saat pembelajaran dengan metode STAD berlangsung. Setelah siswa paham kemudian guru membagi siswa menjadi beberapa kelompok. Pembagian kelompok berdasarkan tingkat prestasi siswa, jadi dalam satu kelompok terdapat siswa dengan tingkat prestasi tinggi, sedang dan rendah sesuai dengan rencana yang telah dibuat, kegiatan pembelajaran dilakukan dengan menggunakan metode pembelajaran STAD.

Guru menjelaskan materi larangan pergaulan bebas dan mendekati zina pada Q.S Q.S Al-Isra': 32 dan Q.S An-Nur: 2 selama 15 menit (Departemen Agama, 2005). Setelah penjelasan selesai, siswa diberi kesempatan untuk bertanya mengenai materi tersebut. Kemudian guru memberikan tugas untuk didiskusikan dan dikerjakan oleh masingmasing kelompok. Setiap kelompok diberikan lembar kegiatan yang berisi pertanyaanpertanyaan terkait dengan materi. Saat belajar kelompok guru berkeliling kelas sambil memantau pekerjaan kelompok dan membantu jika ada kelompok yang mengalami kesulitan dalam mengerjakan tugasnya. Terkadang guru memanggil siswa secara acak dan memberikan pertanyaan kepada siswa dikala mereka berdiskusi, hal ini bertujuan agar semua siswa selalu siap dan mau berdiskusi dengan baik.

Setelah siswa menyelesaikan tugas yang diberikan, lalu guru meminta 2 kelompok untuk mempresentasikan tugasnya di depan kelas secara sukarela. Saat presentasi berjalan, beberapa siswa sudah berani bertanya dan kelompok presentasi pun langsung menanggapinya. Selain itu ada juga siswa yang menanggapi dan memberi masukan ketika jawaban dari kelompok presentasi kurang lengkap. Ada juga siswa yang menyanggah pertanyaan dan jawaban dari siswa lain. Setelah presentasi berakhir guru memberikan kesimpulan dari materi yang telah disampaikan dan masing-masing kelompok mengumpulkan tugasnya.

Pada akhir pertemuan siklus I guru melakukan tes yang berupa kuis individu. Tes dilakukan dalam waktu 45 menit. Soal tes terdiri dari 10 soal berbentuk essay. Saat pelaksanaan tes, guru berkeliling memantau siswa dan selalu mengingatkan agar siswa tidak bekerja sama dalam mengerjakan tes. Setelah waktu tes telah habis semua siswa harus mengumpulkan semua tugasnya. Kemudian guru mengumumkan kelompok yang mendapatkan reward pada pertemuan siklus I.

\section{Siklus II}

Pada siklus II dilaksanakan pada hari Kamis tanggal 14 Agustus 2014 pada jam pelajaran 1-3 dengan waktu perjamnya 45 menit sehingga total waktu untuk proses pembelajaran materi larangan pergaulan bebas dan mendekati zina khususnya pada kompetensi dasar memahami hikmah dan manfaat larangan pergaulan bebas dan 
perbuatan zina berlangsung selama 135 menit dengan jumlah siswa 35 orang.

Pada siklus II, guru memulai pembelajaran dengan apersepsi menyampaikan tujuan pembelajaran. Pertanyaan dilontarkan kepada siswa mengenai manfaat dan hikmah larangan pergaulan bebas dan zina. Guru kembali menjelaskan bahwa pembelajaran masih menggunakan metode STAD kepada siswa, kemudian guru membagi lagi siswa menjadi beberapa kelompok. Guru menjelaskan materi tentang hikmah dan manfaat larangan pergaulan bebas dan mendekati zina selama 15 menit. Setelah penjelasan selesai, siswa diberi kesempatan untuk bertanya mengenai materi tersebut.

Guru memberikan tugas untuk didiskusikan dan dikerjakan oleh masingmasing kelompok. Setiap kelompok diberikan lembar kegiatan yang berisi pertanyaanpertanyaan terkait dengan materi. Saat belajar kelompok guru berkeliling kelas sambil memantau pekerjaan kelompok dan membantu jika ada kelompok yang mengalami kesulitan dalam mengerjakan tugasnya. Kegiatan belajar berjalan dengan baik, siswa mulai aktif dengan kelompok masing-masing. Terkadang guru memanggil siswa yang nilainya masih dibawah standar kompetensi pada siklus I secara acak dan memberikan pertanyaan kepada siswa dikala mereka berdiskusi.

Setelah siswa menyelesaikan tugas yang diberikan, lalu guru meminta 3 kelompok yang belum presentasi pada siklus I untuk mempresentasikan tugasnya di depan kelas secara sukarela. Saat presentasi berjalan, beberapa siswa sudah berani bertanya dan kelompok presentasi pun langsung menanggapinya. Selain itu ada juga siswa yang menanggapi dan memberi masukan ketika jawaban dari kelompok presentasi kurang lengkap. Ada juga siswa yang menyanggah pertanyaan dan jawaban dari siswa lain. Setelah presentasi berakhir guru memberikan kesimpulan dari materi yang telah disampaikan dan masing-masing kelompok mengumpulkan tugasnya.

Pada akhir pertemuan siklus II guru melakukan tes yang berupa kuis individu. Tes dilakukan dalam waktu 45 menit. Soal tes terdiri dari 10 soal berbentuk essay. Saat pelaksanaan tes, guru berkeliling memantau siswa dan selalu mengingatkan agar siswa tidak bekerja sama dalam mengerjakan tes. Setelah waktu tes telah habis semua siswa harus mengumpulkan semua tugasnya. Kemudian guru mengumumkan kelompok yang mendapatkan reward pada pertemuan siklus II.

\section{Siklus III}

Pada siklus III dilaksanakan pada hari Kamis tanggal 21 Agustus 2014 pada jam pelajaran 1-3 dengan waktu perjamnya 45 menit sehingga total waktu untuk proses pembelajaran materi larangan pergaulan bebas dan mendekati zina khususnya pada kompetensi dasar membaca dan mendemonstrasikan Q.S Al-Isra': 32 dan Q.S An-Nur: 2 serta hadits tentang larangan pergaulan bebas dan perbuatan zina berlangsung selama 135 menit dengan jumlah siswa 35 orang.

Pada siklus III, guru kembali mengingatkan tentang materi pada pertemuan sebelumnya dan menyampaikan tujuan pembelajaran. Guru kembali menjelaskan penggunaan metode pembelajaran STAD kepada siswa dan membagi lagi siswa menjadi beberapa kelompok. Guru menjelaskan materi larangan pergaulan bebas dan mendekati zina pada Q.S 
Q.S Al-Isra': 32 dan Q.S An-Nur: 2 selama 15 menit. Saat guru menjelaskan materi, siswa terlihat antusias dalam memperhatikan penjelasan dari guru. Siswa ikut aktif dengan mengutarakan jawaban serta pertanyaan kecil.

Guru memberikan tugas untuk didiskusikan dan dikerjakan oleh masingmasing kelompok. Setiap kelompok diberikan lembar kegiatan yang berisi pertanyaanpertanyaan terkait dengan materi. Saat belajar kelompok guru berkeliling kelas sambil memantau pekerjaan kelompok dan memberi motivasi agar siswa aktif dalam belajar kelompok dan guru juga memberi keluasaan kepada siswa untuk bertanya bila ada yang belum paham tentang materi yang disampaikan. Kegiatan belajar berjalan dengan baik, siswa terlihat aktif dengan kelompok masing-masing dan mampu berdiskusi secara lancar dan mampu membagi tugas masingmasing individu. Siswa yang mengalami kesulitan tidak segan untuk bertanya kepada teman yang sudah paham dan beberapa siswa juga bertanya kepada guru.

Setelah siswa menyelesaikan tugas yang diberikan, lalu guru meminta 3 kelompok yang belum presentasi pada siklus I dan II untuk mempresentasikan tugasnya di depan kelas. Saat presentasi berjalan, beberapa siswa sudah berani bertanya dan kelompok presentasi pun langsung menanggapinya. Selain itu ada juga siswa yang menanggapi dan memberi masukan ketika jawaban dari kelompok presentasi kurang lengkap. Ada juga siswa yang menyanggah pertanyaan dan jawaban dari siswa lain. Setelah presentasi selesai, guru bersama-sama dengan siswa mengambil kesimpulan dari materi yang telah dipelajari. Guru meminta kepada siswa untuk mengumpulkan hasil kerja kelompok. Pada akhir pertemuan siklus III guru melakukan tes yang berupa hapalan per individu. Setelah semua siswa sudah hapalan di depan guru, kemudian guru mengumumkan kelompok yang mendapatkan reward pada pertemuan siklus III.

Dalam penerapan metode pembelajaran STAD (Student Teams Achievement Division) pada materi larangan pergaulan bebas dan mendekati zina kelas X IPA1SMA Negeri 3 Metro semester ganjil tahun pelajaran 2016/2017 terlaksana dalam tiga siklus yang masing-masing siklus berjalan sesuai dengan tujuan proses pembelajaran.

\section{Peningkatan Prestasi Belajar Siswa melalui Metode STAD (Student Teams Achievement Division) pada Materi Larangan Pergaulan Bebas dan Mendekati Zina}

Peningkatan prestasi belajar siswa diperoleh dari pembelajaran yang dilakukan siswa pada siklus I, siklus II dan siklus III. Tingkat keberhasilan dari metode pembelajaran STAD pada materi larangan pergaulan bebas dan mendekati zina kelas $\mathrm{X}$, terlihat pada aktivitas siswa dalam belajar kelompok yang mengalami peningkatan setiap siklusnya. Sebagaimana yang dikemukakan oleh salah satu siswa yang bernama Achmad Faisal bahwa sangat senang belajar menggunakan metode STAD, dengan adanya diskusi kelompok akan menambah wawasan antara siswa yang lainnya yang belum mengetahui tentang materi yang sedang dipelajari, dapat bertukar pemikiran, mengerti arti kerjasama dan kebersamaan bersama kelompok belajarnya dan dapat memiliki 
prestasi belajar yang sebelum malas dalam belajar.

Pada siklus I, siswa terlihat belum aktif dan belum terlihat prestasinya dalam proses pembelajaran khususnya pada materi larangan pergaulan bebas dan mendekati zina karena siswa belum mengetahui metode STAD (Student Teams Achievement Division) yang diterapkan. Akan tetapi setelah siswa mulai mempraktekkan metode STAD, siswa menjadi aktif, keinginantahuan dalam belajar menjadi meningkat dan siswa sedikit demi sedikit telah menunjukkan prestasinya dalam proses pembelajaran. Sebagaimana yang dikemukakan oleh salah satu guru PAI lainnya yang mengatakan bahwa secara umum perhatian, keaktifan dan kerjasama siswa sudah cukup baik dibandingkan dengan awal sebelum diterapkan model pembelajaran STAD.

Slavin memaparkan bahwa gagasan utama metode STAD tidak hanya untuk meningkatkan prestasi belajar siswa saja tetapi memacu siswa agar saling mendorong dan membantu satu sama lain untuk menguasai keterampilan yang diajarkan oleh guru. Bukti yang menghubungkan STAD (Student Teams Achievement Divisions) dengan hasil yang diperoleh dalam hubungan pertemanan lintasrasial terlihat kuat dalam proses pembelajaran siswa yang melaksanakan STAD (Student Teams Achievement Divisions) selama proses pembelajaran berlangsung memperoleh hubungan lintas-rasial yang lebih banyak daripada para siswa dalam kelas kontrol dan menemukan perolehan yang signifikan dalam pertemanan siswa. Hal tersebut sesuai dengan hasil wawancara salah satu siswa yang bernama Anggun Desvita yang mengemukakan bahwa sebelum mengikuti metode pembelajaran STAD tidak banyak mengenal antara semua siswa walaupun satu kelas dan jarang mengobrol antara teman sekelas, akan tetapi setelah melaksanakan metode pembelajaran STAD semua siswa menjadi akrab dan saling membantu dengan siswa yang satu dengan siswa yang lainnya jika mengalami kesulitan.

Prestasi siswa dapat diketahui oleh guru dengan cara melakukan pengukuran dan evaluasi sehingga prestasi belajar menjadi hasil evaluasi belajar yang dicapai siswa setelah mengalami proses belajar. Proses belajar yang dialami oleh siswa menghasilkan perubahan-perubahan dalam bidang pengetahuan, pemahaman, keterampilan, nilai dan sikap. Adanya perubahan itu tampak dalam prestasi belajar yang dihasilkan oleh siswa terhadap tugas yang diberikan guru. Hal tersebut sesuai dengan hasil wawancara oleh salah satu siswa lain yang bernama Selvia Suci yang mengemukakan bahwa selama mengikuti 3 siklus pelajaran PAI khususnya pada materi larangan pergaulan bebas dan mendekati zina telah mengalami banyak perubahan terutama dalam hasil ulangan, yang pada awal belajar siklus I hanya mendapatkan nilai 70 hasil ulangan dan sekarang setelah selalu mengasah proses pembelajarannya hasil ulangannya menjadi 90 pada siklus II dan III.

Adapun hasil dari prestasi belajar siswa tersebut terbukti dari tes yang dilakukan pada akhir pembelajaran. Tes dilakukan dalam waktu 45 menit. Soal tes terdiri dari 10 butir soal berbentuk essay. Hasil belajar dapat dilihat pada beberapa tabel berikut berikut: 
Tabel 1.

Hasil Pembelajaran Siswa Sebelum Melaksanakan Metode STAD

\begin{tabular}{|l|l|l|l|}
\hline No & Nilai & Frekuensi & $\begin{array}{l}\text { Frekuensi } \\
\text { Relatif (\%) }\end{array}$ \\
\hline 1 & $50-54$ & 5 & 14,30 \\
\hline 2 & $55-59$ & 9 & 25,74 \\
\hline 3 & $60-64$ & 7 & 20,02 \\
\hline 4 & $65-69$ & 4 & 11,44 \\
\hline 5 & $70-74$ & 0 & 0 \\
\hline 6 & $75-80$ & 10 & 28,60 \\
\hline Jumlah & 35 & 100 \\
\hline
\end{tabular}

Jumlah siswa yang mencapai KKM baru sebanyak 10 siswa dan 25 siswa belum mencapai nilai KKM sekolah sehingga persentase ketuntasan siswa hanya sebesar $28,60 \%$.

Tabel 2.

Hasil Pembelajaran Siswa Siklus I

\begin{tabular}{|l|l|l|l|}
\hline No & Interval & Frekuensi & $\begin{array}{l}\text { Frekuensi } \\
\text { Relatif (\%) }\end{array}$ \\
\hline 1 & $55-59$ & 1 & 2,86 \\
\hline 2 & $60-64$ & 2 & 5,72 \\
\hline 3 & $65-69$ & 3 & 8,58 \\
\hline 4 & $70-74$ & 6 & 17,16 \\
\hline 5 & $75-79$ & 11 & 31,46 \\
\hline 6 & $80-84$ & 7 & 20,02 \\
\hline 7 & $85-90$ & 5 & 14,30 \\
\hline \multicolumn{2}{|l|}{ Jumlah } & 35 & 100 \\
\hline
\end{tabular}

Jumlah siswa yang mencapai KKM baru sebanyak 23 siswa dan 12 siswa belum mencapai nilai KKM sekolah sehingga persentase ketuntasan siswa hanya sebesar $65,78 \%$.

Tabel 3

Hasil Pembelajaran Siswa Siklus II

\begin{tabular}{|l|l|l|l|}
\hline No & Interval & Frekuensi & $\begin{array}{l}\text { Frekuensi } \\
\text { Relatif }(\%)\end{array}$ \\
\hline 1 & $70-74$ & 5 & 14,30 \\
\hline 2 & $75-79$ & 6 & 17,16 \\
\hline 3 & $80-84$ & 7 & 20,02 \\
\hline 4 & $85-89$ & 10 & 28,60 \\
\hline 5 & $90-94$ & 4 & 11,44 \\
\hline 6 & $95-100$ & 3 & 8,58 \\
\hline Jumlah & 35 & 100 \\
\hline
\end{tabular}

Jumlah siswa yang mencapai KKM baru sebanyak 30 siswa dan 5 siswa belum mencapai nilai KKM sekolah sehingga persentase ketuntasan siswa hanya sebesar $85,80 \%$.

Tabel 4

Hasil Pembelajaran Siswa Siklus III

\begin{tabular}{|l|l|l|l|}
\hline No & Interval & Frekuensi & $\begin{array}{l}\text { Frekuensi } \\
\text { Relatif }(\%)\end{array}$ \\
\hline 1 & $75-79$ & 6 & 17,16 \\
\hline 2 & $80-84$ & 7 & 20,02 \\
\hline 3 & $85-89$ & 10 & 28,60 \\
\hline 4 & $90-94$ & 7 & 20,02 \\
\hline 5 & $95-100$ & 5 & 14,30 \\
\hline \multicolumn{2}{|l|}{ Jumlah } & 35 & 100 \\
\hline
\end{tabular}

Jumlah siswa yang mencapai KKM sudah semua siswa mencapai nilai KKM sekolah sehingga persentase ketuntasan siswa sebesar $100 \%$.

Berdasarkan hasil wawancara dengan informan tersebut peneliti dapat menyimpulkan bahwa proses pembelajaran yang menggunakan metode pembelajaran STAD terlaksana dengan efektif dan optimal dalam belajar sehingga tujuan proses pembelajaran akan tercapai dengan hasil yang memuaskan dan meningkatkan prestasi belajar siswa. Hal tersebut terbukti dengan diterapkannya metode pembelajaran STAD di kelas X IPA1SMA Negeri 3 Metro semester ganjil tahun pelajaran 2016/2017 pada materi larangan pergaulan bebas dan mendekati zina, pada setiap siklus mengalami peningkatan hasil prestasi belajar siswa.

\section{KESIMPULAN}

Efektifitas setelah diterapkannya metode pembelajaran STAD maka seluruh siswa menjadi paham dan aktif dalam belajar. Pelaksanaan pembelajaran dengan 
menerapkan metode STAD, terdapat enam tahap yaitu guru menyampaikan materi pembelajaran, guru membagi siswa ke dalam beberapa kelompok, diskusi kelompok untuk penguatan materi, presentasi hasil diskusi secara sukarela, guru memberikan tes secara individual dan guru memberi poin lebih (reward) kepada kelompok yang memiliki nilai rata-rata tertinggi.

Penerapan metode pembelajaran STAD (Student Teams Achievement Division) dalam materi larangan pergaulan bebas dan mendekati zina pada siswa kelas X IPA1SMA Negeri 3 Metro semester ganjil tahun pelajaran 2016/2017 dapat meningkatkan prestasi belajar siswa dengan dibuktikannya proses pembelajaran persiklus mengalami peningkatan yaitu pada siklus I mencapai ketuntasan belajar 65,78\% yang tuntas 23 siswa dari 35 siswa, pada siklus II mencapai ketuntasan belajar 85,80 yang tuntas 30 siswa dari 35 siswa dan pada siklus III mencapai ketuntasan belajar $100 \%$ semua siswa tuntas dalam belajar.

\section{DAFTAR PUSTAKA}

Arikunto, S. (2007). Penelitian Tindakan Kelas (Jakarta: PT Bumi Aksara, 2008). Cetakan Ketujuh, Hlm, 3.

Baharuddin, dkk. 2008. Teori Belajar dan Pembelajaran. Jogyakarta: Ar-Ruzz Media

Departemen Agama, R. I. (2005). al-Quran dan Terjemahnya. Bandung: Diponegoro.

Hamzah, B. U. (2007). Profesi kependidikan. Jakarta: Bumi Aksara.

Kusumah, W., \& Dwitagama, D. (2010). Mengenal penelitian tindakan kelas edisi kedua. Jakarta: PT Indeks.

Moleong, L. (2013). J. 2007. Metodologi Penelitian Kualitatif, 4-10.

Slavin, R. E. (2005). Cooperative learning teori, riset dan praktik. Bandung: Nusa Media, 236.

Sugiyono. 2009. Model-model Pembelajaran Inovatif. Surakarta: Yuma Pusaka

Sudjana, N. (2005). Proses belajar mengajar. Dasar-Dasar Proses Belajar Mengajar, Bandung: Sinar Baru Algensindo. 